\title{
Kinerja Algoritma Optimasi Root-Mean-Square Propagation dan Stochastic Gradient Descent pada Klasifikasi Pneumonia Covid-19 Menggunakan CNN
}

\author{
Budi Nugroho $^{\# 1}$, Eva Yulia Puspaningrum ${ }^{\# 2}$, M. Syahrul Munir ${ }^{* 3}$ \\ "Program Studi Informatika, Fakultas Ilmu Komputer, Universitas Pembangunan Nasional “Veteran” Jawa Timur \\ Jl. Raya Rungkut Madya, Gunung Anyar, Surabaya \\ 1 budinugroho.if@upnjatim.ac.id \\ evapuspaningrum.if@upnjatim.ac.id \\ *Program Studi Teknik Informatika, Akademi Komunitas Negeri Pacitan \\ Jl. Walanda Maramis 04a, Pacitan \\ ${ }^{3}$ syahruldaknpacitan.ac.id
}

\begin{abstract}
Abstrak- Penelitian ini berkaitan dengan proses klasifikasi Pneumonia Covid-19 (radang paru-paru atau pneumonia yang disebabkan oleh virus corona SARS-CoV-2) dari citra hasil foto rontgen / $\mathrm{x}$-ray paru-paru dengan menggunakan pendekatan pembelajaran mesin. Klasifikasi dilakukan untuk menentukan apakah kondisi paru-paru seseorang mengalami Pneumonia Covid-19, Pneumonia biasa, atau Normal / Sehat. Untuk menghasilkan kinerja klasifikasi yang lebih baik, proses optimasi seringkali digunakan pada tahap pelatihan data. Banyak teknik yang digunakan untuk melakukan optimasi tersebut, diantaranya adalah algoritma Root-MeanSquare Propagation (RMSprop) dan Stochastic Gradient Descent (SGD). Pada penelitian ini, pengujian dilakukan terhadap kedua metode tersebut untuk mengetahui kinerjanya pada klasifikasi Pneumonia Covid-19. Metode klasifikasi menggunakan Convolutional Neural Network (CNN) yang menerapkan 5 layer konvolusi dengan nilai filter 16, 32, 64, 128, dan 256. Proses pelatihan menggunakan 3.900 citra yang terdiri atas 1.300 citra pneumonia covid-19, 1.300 citra pneumonia, dan 1.300 citra normal. Sedangkan proses validasi menggunakan 450 citra dan proses pengujian mengunakan 225 citra. Berdasarkan uji coba yang telah dilakukan, implementasi algoritma optimasi RMSprop menghasilkan akurasi $87,99 \%$, presisi 0,88 , recall 0,86 , dan f1 score 0,87 . Sedangkan implementasi algoritma optimasi SGD menghasilkan akurasi $66,22 \%$, presisi 0,69 , recall 0,64 , dan $f 1$ score 0,67 . Hasil ini memberikan informasi penting bahwa algoritma optimasi RMSprop menghasilkan kinerja yang jauh lebih baik daripada SGD pada klasifikasi Pneumonia Covid-19.
\end{abstract}

Kata Kunci- Pneumonia Covid-19, Optimasi, RMSprop, SGD, CNN, Kinerja Klasifikasi.

\section{Pendahuluan}

Paru-paru merupakan organ sangat vital bagi kesehatan dan keberlangsungan hidup manusia. Pneumonia merupakan kondisi gangguan kesehatan pada paru-paru yang bisa terjadi ketika paru-paru mengalami peradangan akibat infeksi yang terjadi pada kantong-kantong udaranya. Umumnya kondisi pneumonia ini ditandai dengan adanya peningkatan opasitas dimana terjadi penebalan corak pembuluh darah atau adanya bercak paru [1]. Penyakit ini merupakan bentuk gangguan kesehatan yang seringkali disebabkan oleh organisme bakteri, virus, dan jamur akibat perubahan kondisi lingkungan, perubahan iklim, gaya hidup, polusi, dan berbagai faktor lainnya [2]. Gejala yang biasa muncul adalah batuk berdahak yang disebabkan oleh saluran pernafasan dalam paru yang mengalami peradangan. Selain itu penderitanya dapat mengalami demam, nyeri dada, kesulitan bernafas, dan kegagalan organ.

Pneumonia semakin menjadi masalah kesehatan serius seiring merebaknya Covid-19 sejak akhir tahun 2019, yang kemudian pada maret 2020 dinyatakan oleh Organisasi Kesehatan Dunia WHO sebagai pandemi [3]. Virus Corona SARS-CoV-2 penyebab Covid-19 ini menyerang saluran pernafasan dan dengan sendiri mengakibatkan terjadinya pneumonia, dari kondisinya ringan hingga berat bahkan menyebabkan kematian. Pneumonia akibat Covid-19 inilah yang kemudian dinamakan dengan pneumonia covid-19. Situasi tersebut tentunya menjadikan pneumonia perlu mendapatkan perhatian serius dan penanganan medis secara tepat [4].

Secara medis, untuk mengetahui kondisi paru-paru mengalami pneumonia covid-19, pneumonia non covid-19 (pneumonia yang dipengaruhi faktor lain), ataukah normal, 
para dokter atau ahli radiologi perlu melihat citra paru-paru hasil foto rontgen (x-ray) bagian dada, sebagaimana ditunjukkan pada gambar 1. Gambar tersebut menunjukkan seseorang mengalami pneumonia covid-19, pneumonia non covid-19 (pneumonia yang disebabkan oleh faktor lain selain covid-19), dan kondisi normal. Bagi orang awam kebanyakan, tentu sulit membedakan ketiga citra tersebut, tetapi bagi para dokter atau ahli radiologi yang memiliki pengetahuan dan pengalaman di bidangnya, tentu lebih mudah menganalisis citra tersebut. Tetapi, ketika citra yang perlu dianalisis dalam jumlah yang sangat banyak, tentunya perlu mekanisme yang lebih efisien. Teknik pendeteksian citra paru-paru hasil foto rontgen yang dapat dilakukan secara otomatis tentunya sangat membantu persoalan ini.
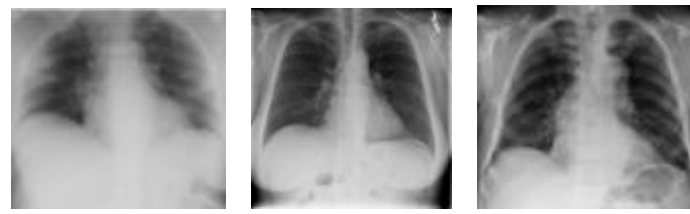

Gambar 1. Citra hasil foto rontgen yang menunjukkan Pneumonia Covid19 (kiri), Pneumonia Non Covid-19 (tengah), dan Normal (kanan)

Banyak penelitian yang telah dikembangkan untuk menganalisis informasi diagnostik dari citra X-ray menggunakan model pembelajaran mesin [5]. Pendekatan pembelajaran mersin yang saat ini banyak digunakan adalah metode Convolutional Neural Network (CNN) yang memang menunjukkan kinerja sangat baik berkaitan dengan klasifikasi obyek. Banyak penelitian berkaitan dengan pengembangan metode ini. Misalnya sebuah penelitian yang menggunakan $\mathrm{CNN}$ dengan model RetinaNet dan Mask R-CNN untuk meningkatkan kinerja pendeteksian pneumonia [6]. Penelitian lainnya memodifikasi arsitektur CNN menjadi 4 layer Konvolusional, 4 layer Max-pooling, 1 Flatten, 7 layer Dense, serta menambahkan proses augmentasi data [7]. Ada pula model Light Convolutional Neural Network yang dikembangkan dari SqueezeNet [8]. Metode GraphKnowledge Embbeded CNN juga dikembangkan pada proses pelatihan data untuk meningkatkan kinerja klasifikasi [9]. Demikian juga penelitian sebelumnya yang menguji model CNN lain VGG16, VGG19, ResNet50, dan Inception-v3, untuk mendeteksi pneumonia [10].

Pada penelitian ini, ruang lingkup pembahasan berkaitan dengan analisis citra digital hasil akuisisi obyek paru-paru dari foto rontgen dengan memanfaatkan model pembelajaran mesin untuk mendeteksi kondisi paru-paru seseorang, apakah sedang mengalami peradangan akibat covid-19 (pneumonia covid-19) atau tidak (pneumonia biasa akibat faktor lain atau kondisi normal / tidak mengalami peradangan). Untuk mendapatkan kinerja klasifikasi yang lebih baik, model pembelajaran mesin umumnya menggunakan proses optimasi pada tahap pelatihan data. Tujuan penelitian adalah untuk mengetahui sejauhmana pengaruh proses optimasi tersebut terhadap kinerja klasifikasi pneumonia covid-19. Banyak teknik yang digunakan untuk melakukan optimasi tersebut, diantaranya adalah algoritma Root-Mean-Square
Propagation / RMSprop [11] dan Stochastic Gradient Descent / SGD [12]. Pada penelitian ini, pengujian dilakukan terhadap kedua metode tersebut untuk mengetahui kinerjanya pada klasifikasi Pneumonia Covid19.

\section{Metodologi Penelitian}

Bagian ini menjelaskan tentang langkah-langkah yang dilakukan untuk mencapai tujuan penelitian. Selain itu juga membahas mengenai algoritma optimasi yang digunakan pada model pembelajaran mesin, metode klasifikasi, dataset citra untuk pengujian, dan skenario uji coba.

\section{A. Langkah-langkah Penelitian}

Untuk mencapai tujuan penelitian ini, beberapa langkah dilakukan, sebagaimana ditunjukkan melalui gambar 2 . Pada tahap awal, arsitektur CNN dirancang untuk menghasilkan model yang akan digunakan sebagai mesin pembelajaran. Selanjutnya, dataset citra disiapkan untuk proses uji coba, meliputi kumpulan citra latih, citra validasi dan citra evaluasi. Dengan menggunakan data set ini, proses pengujian dilakukan terhadap model CNN dengan menerapkan teknik optimasi SMRprop dan SGD, yang kemudian diukur kinerjanya menggunakan akurasi, presisi, recall, dan f1 score. Hasil kinerja dari kedua teknik optimasi tersebut dibandingkan untuk mengetahui teknik mana yang menghasilkan kinerja lebih baik.

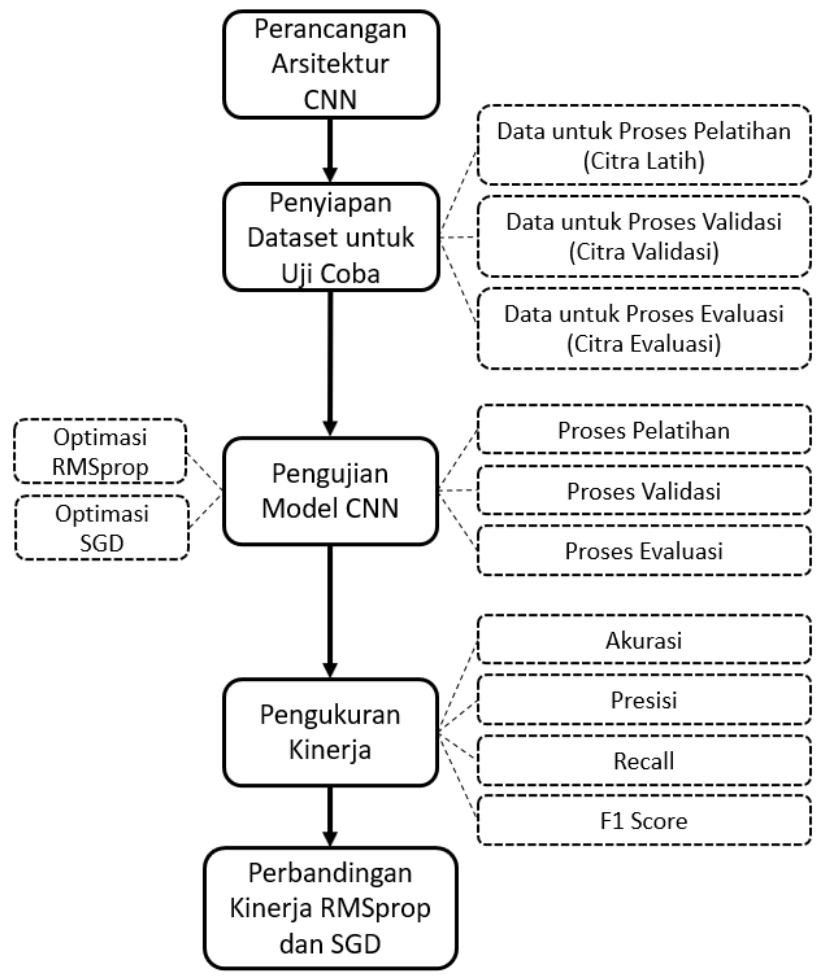

Gambar 2. Langkah-langkah penelitian

\section{B. Algoritma Optimasi}

Algoritma optimasi seringkali digunakan pada model pembelajaran mesin untuk menghasilkan kinerja klasifikasi yang tinggi. Pada penelitian ini, algoritma Root-Mean- 
Square Propagation (RMSprop) dan algoritma Stochastic gradient descent (SGD) dibandingkan untuk mengetahui pendekatan mana yang menghasilkan kinerja klasifikasi lebih baik.

Algoritma RMSprop dirancang untuk pelatihan Jaringan Syaraf Tiruan dengan tingkat pembelajaran adaptif yang berbeda dan berasal dari konsep penurunan gradien dan Resilient Back Propagation (RProp), berada di ranah metode tingkat pembelajaran adaptif, yang semakin populer dalam beberapa tahun terakhir karena merupakan pengembangan dari beberapa pendekatan lain. Pendekatan ini menggabungkan rata-rata pada mini-batch, efisiensi, dan gradien pada mini-batch yang berurutan, sehingga dapat mencapai tingkat konvergensi yang lebih cepat daripada pendekatan optimasi dasar, tetapi lebih rendah daripada pendekatan optimasi lanjutan seperti algoritma Adam. Salah satu aplikasi RMSProp adalah teknologi stokastik untuk penurunan gradien mini-batch. RMSProp dirancang untuk mengatasi permasalahan yang terjadi pada algoritma Resilient Back Propagation (RPop) yang tidak bekerja untuk mini-batch. Dengan menggunakan tanda gradien dari algoritma RPop, efisiensi mini-batch, dan ratarata di atas mini-batch yang memungkinkan penggabungan gradien secara tepat [13].

Sedangkan algoritma SGD adalah metode iteratif yang juga biasa digunakan pada pembelajaran mesin dan mengoptimalkan penurunan gradien. Pada pendekatan ini, pengguna menginisialisasi bobot dan proses memperbarui vektor bobot menggunakan satu titik data. Penurunan gradien berlangsung terus secara bertahap ketika perhitungan kesalahan diselesaikan untuk meningkatkan konvergensi [14]. Metode ini berusaha untuk menentukan penurunan paling curam dan mengurangi jumlah iterasi dan waktu yang diperlukan untuk mencari titik data dalam jumlah besar. Penurunan gradien stokastik digunakan dalam jaringan saraf dan mengurangi waktu komputasi mesin sambil meningkatkan kompleksitas dan kinerja untuk masalah skala besar. Algoritma SGD memodifikasi algoritma batch gradient descent dengan menghitung gradien hanya untuk satu contoh pelatihan pada setiap iterasi [15]. Pendekatan ini menyediakan banyak aplikasi dalam pembelajaran mesin, geofisika, least mean squares (LMS), dan area lainnya.

\section{Metode Klasifikasi}

Metode klasifikasi pada penelitian ini adalah Convolutional Neural Network (CNN). Gambar 3 menunjukkan arsitektur CNN yang digunakan pada penelitian ini. Pada arsitektir ini terdapat 5 lapisan konvolusi dengan nilai filter 16, 32, 64, 128, dan 256. Lapisan ini merupakan aktivitas utama jaringan syaraf yang diperlukan untuk operasi konvolusi pada output dari lapisan sebelumnya. Pada lapisan ini, ekstraksi fitur dilakukan terhadap citra input, yang selanjutnya menghasilkan transformasi linear dari data input sesuai dengan informasi spasialnya. Proses klasifikasi menggunakan fungsi flattening, fully connected layer, dan dense. Lapisan Dropout ditambahkan untuk mencegah terjadinya overfitting dan mempercepat proses pembelajaran data.

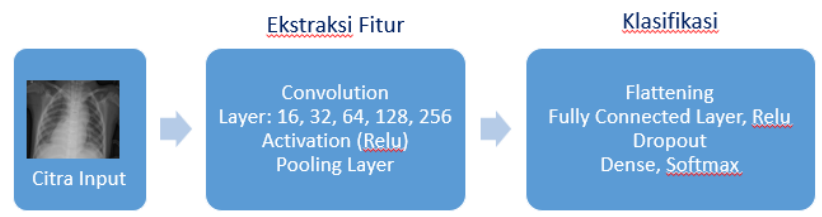

Gambar 3. Arsitektur CNN pada penelitian ini

Model CNN dikembangkan melalui beberapa tahapan, yaitu pembuatan model, pelatihan model, evaluasi model, dan prediksi model. Terdapat 2 proses utama pada model ini, yaitu ekstraksi fitur dan klasifikasi. Output pada sebuah lapisan konvolusi digunakan sebagai input pada lapisan konvolusi berikutnya. Proses klasifikasi menggunakan lapisan fully-connected. Kedua komponen tersebut dilengkapi dengan fungsi aktivasi (dalam hal ini menggunakan fungsi softmax).

\section{Data Uji Coba}

Proses pembelajaran mesin membutuhkan dataset berupa kumpulan data citra dengan jumlah yang memadai. Dataset citra ini dibagi menjadi 3 yaitu data pelatihan, data validasi dan data pengujian. Data pelatihan digunakan pada proses pembelajaran jaringan. Proses berikutnya adalah pengujian data validasi. Dan proses terakhir adalah evaluasi data pengujian untuk menentukan kinerja klasifikasi.

Pada penelitian ini, dataset berupa kumpulan citra paruparu hasil foto rontgen (x-ray), dengan spesifikasi yang ditunjukkan pada tabel 1. Data pelatihan untuk uji coba menggunakan 3.900 citra. Sedangkan untuk proses validasi menggunakan 450 citra dan proses pengujian mengunakan 225 citra.

TABEL I

SPESIFIKASI DATASET UNTUK UJI COBA

\begin{tabular}{|l|c|c|c|}
\hline \multirow{2}{*}{ Proses } & \multicolumn{3}{|c|}{ Citra Input } \\
\cline { 2 - 4 } & $\begin{array}{c}\text { Pneumonia } \\
\text { Covid-19 }\end{array}$ & Pneumonia & Normal \\
\hline Pelatihan & 1.300 & 1.300 & 1.300 \\
\hline Validasi & 150 & 150 & 150 \\
\hline Pengujian & 75 & 75 & 75 \\
\hline
\end{tabular}

Citra Pneumonia Covid-19 pada dataset ini menunjukkan kondisi paru-paru yang mengalami peradangan akibat covid-19. Citra Pneumonia menunjukkan kondisi paru-paru yang mengalami peradangan yang disebabkan oleh faktor selain covid-19 (banteri, virus selain SARS-CoV-2, dan lainnya). Sedangkan citra Normal menunjukkan bahwa kondisi paruparu sehat atau tidak mengalami peradangan.

\section{E. Skenario Pengujian}

Proses uji coba dengan menggunakan dataset citra paruparu ini nantinya menghasilkan kinerja klasifikasi pada proses pelatihan, validasi, dan evaluasi / pengujian. Ukuran kinerja klasifikasi yang digunakan antara lain Akurasi (rentang nilai 0-100\%), Presisi (rentang nilai 0-1), Recall 
(rentang nilai 0-1), dan F Measure / F1 Score (rentang nilai $0-1)$.

Skenario pengujian pada penelitian ini ditunjukkan melalui tabel 2, dimana terdapat 3 proses, yaitu: pelatihan (training), validasi (validation), dan Evaluasi / pengujian (evaluation / testing). Proses pelatihan dilakukan untuk pengembangan model pembelajaran mesin berdasarkan data latih. Proses validasi dilakukan untuk mengevaluasi model yang telah dikembangkan pada fase pelatihan saat pengaturan hyperparameter. Sedangkan proses evaluasi dimaksudkan untuk menguji model akhir.

TABEL II

SKENARIO UJI COBA

\begin{tabular}{|c|c|c|c|}
\hline \multirow{2}{*}{ Uji } & \multicolumn{3}{|c|}{ Pengukuran Kinerja } \\
\cline { 2 - 2 } Coba & Proses & RMSprop & SGD \\
\hline 1 & Pelatihan & Akurasi, & Akurasi, \\
\hline 2 & Validasi & Presisi, Recall, & Presisi, Recall, \\
\hline 3 & Evaluasi & F1 Score & F1 Score \\
\hline
\end{tabular}

Uji coba dilakukan untuk mengetahui kinerja metode optimasi RMSprop dan SGD dalam proses klasifikasi pneumonia covid-19 dengan pendekatan klasifikasi menggunakan $\mathrm{CNN}$.

\section{HASIL DAN PEMBAHASAN}

Uji coba dilakukan secara berulang kali terhadap kode program dengan modifikasi sejumlah parameter, ukuran citra input, layer konvolusi, dan sebagainya. Hal ini perlu dilakukan untuk mencari hasil yang paling baik kinerjanya. Berdasarkan hasil uji coba yang telah dilakukan, diperoleh hasil yang paling baik kinerjanya sebagaimana ditunjukkan pada tabel 3-5 dan gambar 4-11.

Pada proses pelatihan, sebagaimana ditunjukkan pada tabel 3, kinerja pelatihan metode RMSprop jauh lebih baik daripada metode SGD pada epoch pengujian terakhir. Demikian juga pada proses validasi, sebagaimana ditunjukkan pada tabel 4, kinerja validasi metode RMSprop jauh lebih baik daripada metode SGD pada epoch pengujian terakhir.

TABEL III

HASIL UJi COBA 1: KINERJA PADA PROSES PELATIHAN

\begin{tabular}{|l|c|c|c|c|}
\hline \multicolumn{1}{|c|}{ Metode } & Akurasi & Presisi & Recall & F1 Score \\
\hline RMSprop & $91,41 \%$ & 0,92 & 0,90 & 0,91 \\
\hline SGD & $78,28 \%$ & 0,82 & 0,74 & 0,78 \\
\hline
\end{tabular}

TABEL IV

HASIL UJI COBA 1: KINERJA PADA PROSES VALIDASI

\begin{tabular}{|l|c|c|c|c|}
\hline \multicolumn{1}{|c|}{ Metode } & Akurasi & Presisi & Recall & F1 Score \\
\hline RMSprop & $90,00 \%$ & 0,91 & 0,89 & 0,90 \\
\hline SGD & $68,00 \%$ & 0,70 & 0,64 & 0,67 \\
\hline
\end{tabular}

Uji coba pada penelitian ini menggunakan 30 epoch. Secara lebih rinci, hasil akurasi dari metode RMSprop pada epoch 1 sampai dengan 30 selama proses pelatihan dan validasi ditunjukkan melalui gambar 4.

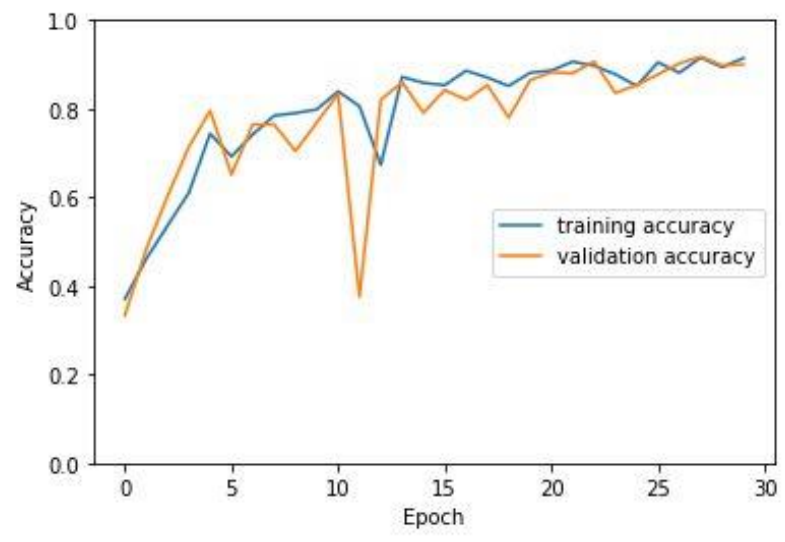

Gambar 4. Grafik nilai akurasi metode RMSprop pada proses pelatihan dan validasi

Adapun hasil presisi dari metode RMSprop pada epoch 1 sampai dengan 30 selama proses pelatihan dan validasi ditunjukkan melalui gambar 5 .

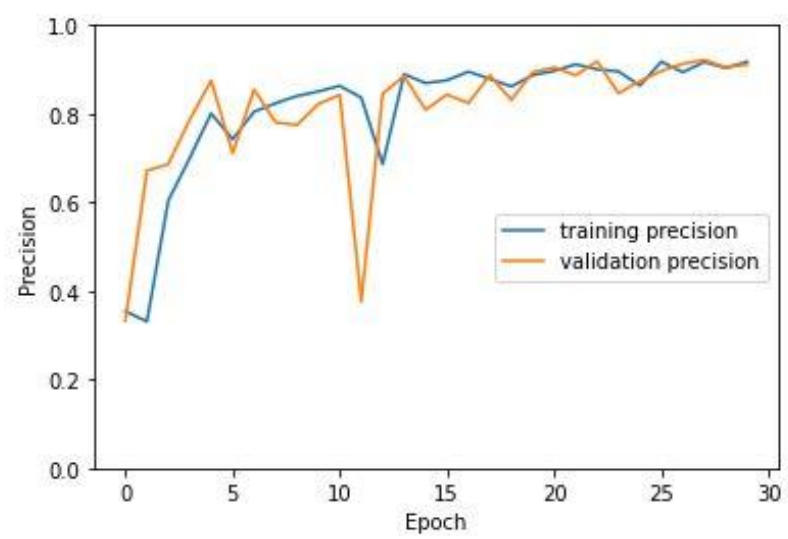

Gambar 5. Grafik nilai presisi metode RMSprop pada proses pelatihan dan validasi

Sedangkan hasil recall dari metode RMSprop pada epoch 1 sampai dengan 30 selama proses pelatihan dan validasi ditunjukkan melalui gambar 6 .

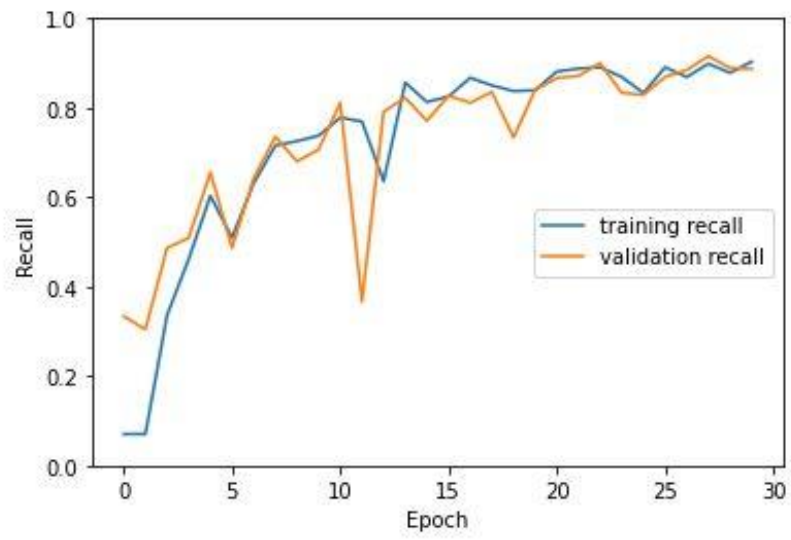

Gambar 6. Grafik nilai recall metode RMSprop pada proses pelatihan dan validasi

Pada proses training dan validasi, loss dari metode RMSprop ditunjukkan melalui gambar 7. 


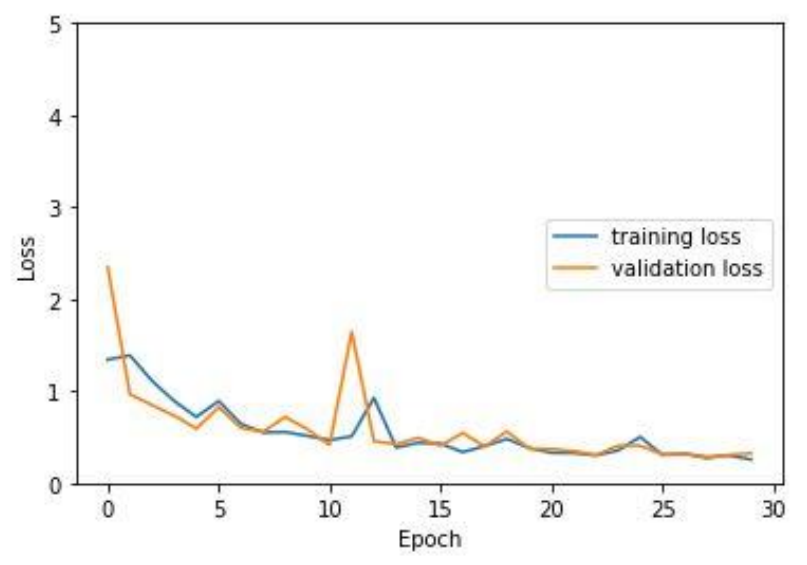

Gambar 7. Grafik nilai loss metode RMSprop pada proses pelatihan dan validasi

Hasil akurasi dari metode SGD pada selama proses pelatihan dan validasi ditunjukkan melalui gambar 8 .

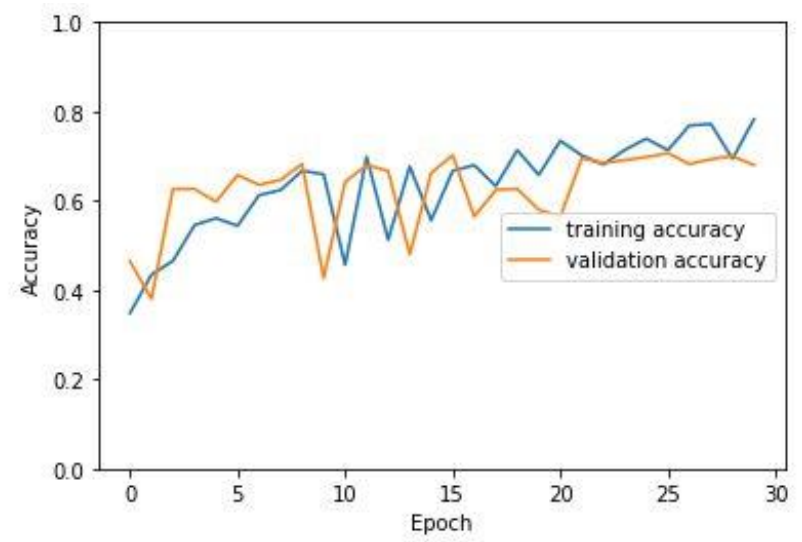

Gambar 8. Grafik nilai akurasi metode SGD pada proses pelatihan dan validasi

Adapun hasil presisi dari metode SGD selama proses pelatihan dan validasi ditunjukkan melalui gambar 9 .

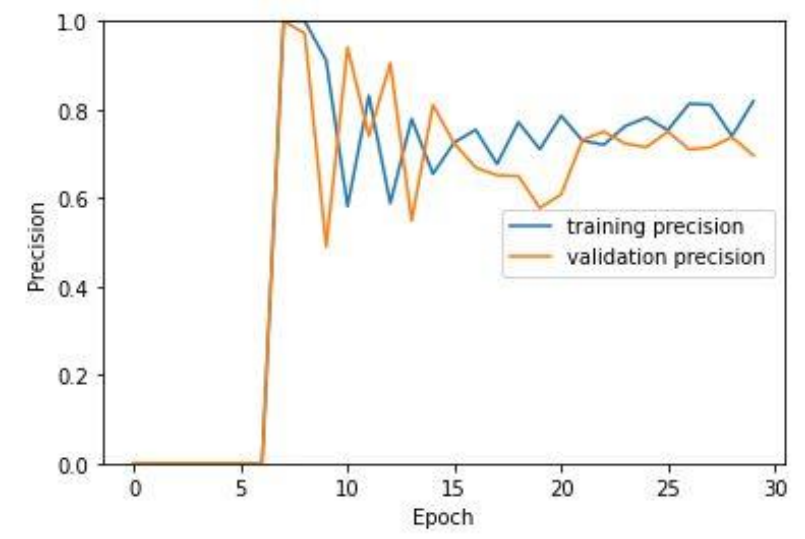

Gambar 9. Grafik nilai presisi metode SGD pada proses pelatihan dan validasi

Sedangkan hasil recall dari metode SGD pada selama proses pelatihan dan validasi ditunjukkan melalui gambar 10 .

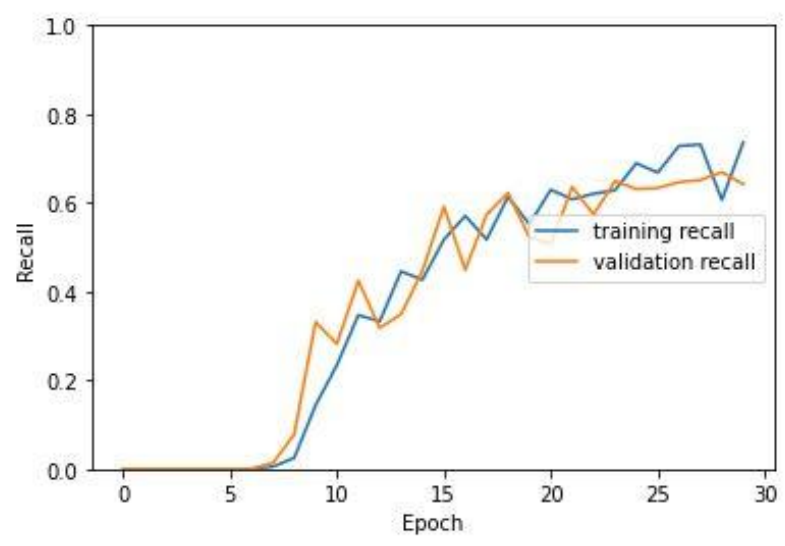

Gambar 10. Grafik nilai recall metode SGD pada proses pelatihan dan validasi

Pada proses training dan validasi, loss dari metode SGD ditunjukkan melalui gambar 11.

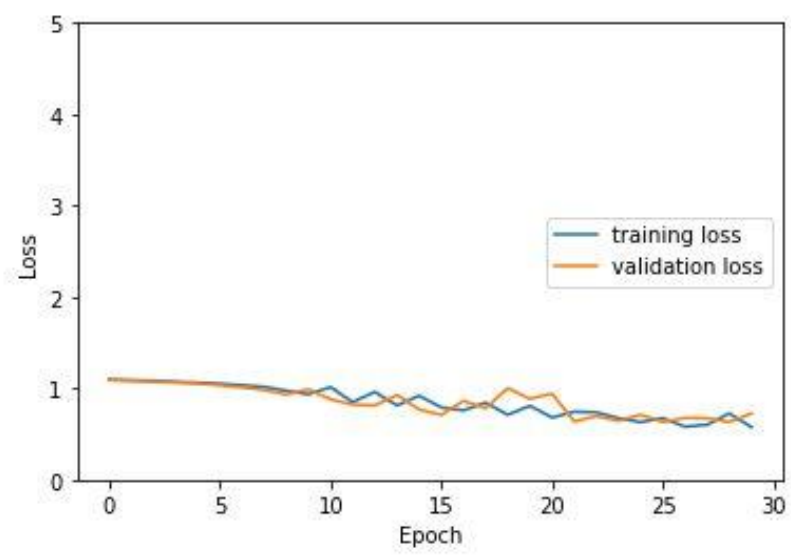

Gambar 11. Grafik nilai loss metode SGD pada proses pelatihan dan validasi

Hasil kinerja pada proses evaluasi atau pengujian akhir menggunakan dataset pengujian ditunjukkan pada tabel 5 . Sebagaimana pada proses pelatihan dan validasi, kinerja metode RMSprop menunjukkan hasil yang jauh lebih baik daripada metode SGD di semua ukuran kinerja.

TABEL V

HASIl UJi COBA 1: KINERJA PADA PROSES EVALUASI

\begin{tabular}{|l|c|c|c|c|}
\hline \multicolumn{1}{|c|}{ Metode } & Akurasi & Presisi & Recall & F1 Score \\
\hline RMSprop & $87,99 \%$ & 0,88 & 0,86 & 0,87 \\
\hline SGD & $66,22 \%$ & 0,69 & 0,64 & 0,67 \\
\hline Selisih & $21,77 \%$ & 0,19 & 0,22 & 0,20 \\
\hline
\end{tabular}

Berdasarkan hasil pada tabel 5 tersebut, akurasi metode RMSprop sebesar 87,99 \% dan SGD sebesar 66,22\%. Presisi metode RMSprop sebesar 0,88 dan SGD sebesar 0,69. Recall metode RMSprop sebesar 0,86 dan SGD sebesar 0,64. Sedangkan f1 score metode RMSprop sebesar 0,87 dan SGD sebesar 0,67. Selisih akurasi antara metode RMRprop dan SGD cukup besar, yaitu sebesar 21,77\%. Demikian juga selisih presisi sebesar 0,19 , recall 0,22 , dan f1 score 0,20 . 


\section{KESIMPULAN}

Berdasarkan uji coba yang telah dilakukan, implementasi algoritma optimasi RMSprop menghasilkan akurasi $87,99 \%$, presisi 0,88 , recall 0,86 , dan $f 1$ score 0,87 . Sedangkan implementasi algoritma optimasi SGD menghasilkan akurasi $66,22 \%$, presisi 0,69 , recall 0,64 , dan f1 score 0,67. Hasil ini memberikan informasi penting bahwa algoritma optimasi RMSprop menghasilkan kinerja yang jauh lebih baik daripada SGD pada klasifikasi Pneumonia Covid-19.

Untuk pengembangan lebih lanjut, proses pengujian perlu dilakukan pada dataset citra yang lebih besar, untuk memastikan apakah hasil penelitian menunjukkan kesimpulan yang sama atau berbeda.

\section{UCAPAN TERIMA KASIH / ACKNOWLEDGMENT}

Tim Peneliti mengucapkan terima kasih kepada LPPM Universitas Pembangunan Nasional "Veteran" Jawa Timur dan Program Studi Informatika Fakultas Ilmu Komputer yang telah memberikan dukungan selama proses penelitian dalam rangka pengembangan ilmu pengetahuan dan teknologi di bidang Ilmu Informatika dan Komputer.

\section{REFERENSI}

[1] T. Franquet, "Imaging of Community-Acquired Pneumonia," $J$ Thorac. Imaging, vol. 33, no. 5, pp. 282-294, 2018, doi 10.1097/RTI.0000000000000347.

[2] S. Bharati, P. Podder, and M. R. H. Mondal, "Hybrid deep learning for detecting lung diseases from X-ray images," Informatics Med. Unlocked, vol. 20, p. 100391, 2020, doi: 10.1016/j.imu.2020.100391.

[3] S. Albahli, "Efficient GAN-based Chest Radiographs (CXR) augmentation to diagnose coronavirus disease pneumonia," Int. J. Med. Sci., vol. 17, no. 10, p. 1439, 2020.

[4] M. Heidari, S. Mirniaharikandehei, A. Z. Khuzani, G. Danala, Y. Qiu, and B. Zheng, "Improving the performance of CNN to predict the likelihood of COVID-19 using chest X-ray images with preprocessing algorithms," Int. J. Med. Inform., vol. 144, p. 104284, Dec. 2020, doi: 10.1016/j.ijmedinf.2020.104284

Q. Z. Song, L. Zhao, X. K. Luo, and X. C. Dou, "Using Deep Learning for Classification of Lung Nodules on Computed Tomography Images," J. Healthc. Eng., vol. 2017, 2017, doi $10.1155 / 2017 / 8314740$.

[6] I. Sirazitdinov, M. Kholiavchenko, T. Mustafaev, Y. Yixuan, R. Kuleev, and B. Ibragimov, "Deep neural network ensemble for pneumonia localization from a large-scale chest x-ray database," Comput. Electr. Eng., vol. 78, pp. 388-399, 2019, doi: 10.1016/j.compeleceng.2019.08.004.

[7] O. Stephen, M. Sain, U. J. Maduh, and D. U. Jeong, "An Efficient Deep Learning Approach to Pneumonia Classification in Healthcare," J. Healthc. Eng., vol. 2019, 2019, doi $10.1155 / 2019 / 4180949$.

[8] M. Polsinelli, L. Cinque, and G. Placidi, "A light CNN for detecting COVID-19 from CT scans of the chest," Pattern Recognit. Lett., vol. 140, pp. 95-100, 2020, doi: 10.1016/j.patrec.2020.10.001.

[9] X. Yu, S. H. Wang, and Y. D. Zhang, "CGNet: A graphknowledge embedded convolutional neural network for detection of pneumonia," Inf. Process. Manag., vol. 58, no. 1, p. 102411, 2021, doi: 10.1016/j.ipm.2020.102411.

[10] R. Jain, P. Nagrath, G. Kataria, V. Sirish Kaushik, and D. Jude Hemanth, "Pneumonia detection in chest X-ray images using convolutional neural networks and transfer learning," Meas. J. Int. Meas. Confed., vol. 165, p. 108046, 2020, doi 10.1016/j.measurement.2020.108046.

[11] T. Tieleman and G. Hinton, "Lecture 6.5-rmsprop: Divide the gradient by a running average of its recent magnitude," COURSERA Neural networks Mach. Learn., vol. 4, no. 2, pp. 26-31, 2012.

[12] I. Sutskever, J. Martens, G. Dahl, and G. Hinton, "On the importance of initialization and momentum in deep learning," 30th Int. Conf. Mach. Learn. ICML 2013, no. PART 3, pp. 2176-2184, 2013.

[13] J. Huang, "RMSProp." 2020, [Online]. Available: https://optimization.cbe.cornell.edu/index.php?title=RMSProp.

[14] D. Needell, N. Srebro, and R. Ward, "Stochastic gradient descent, weighted sampling, and the randomized Kaczmarz algorithm," Math. Program., vol. 155, no. 1-2, pp. 549-573, 2016, doi: 10.1007/s10107-015-0864-7.

[15] S. Ruder, "An overview of gradient descent optimization algorithms," 2020. https://ruder.io/optimizing-gradientdescent/index.html\#batchgradientdescent. 